\title{
Phenotypic plasticity of morphological traits determine the performance of woody species in tropical dry forest
}

\begin{abstract}
In the extremely variable and severe environment of tropical dry forest, the phenotypic plasticity of morphological traits of plant species plays an important role for their development, functioning and evolution. We selected eight morphological traits (viz, girth, GT; height, HT; bark thickness, BT; wood specific gravity, WSG; leaf area, LA; crown cover, CC; crown depth, CD; leaf area index, LAI), which are considered important for the survival and growth of plant species in tropical dry forest, and measured their range in woody species, including trees and shrubs, across the five study sites. We also, measured phenotypic plasticity of morphological trait of each woody species across the study sites. We observed that the woody species, exhibited wide range of morphological traits. The phenotypic plasticity of the morphological traits showed remarkable variation across species as well as within a particular species growing at different levels of soil moisture content. The relationships of mean value of morphological traits across all woody species at five study sites with the respective mean value of soil properties were significant. Among the selected traits, LA and HT were most important for the variation in SR at our study sites. We suggest extensive investigation of the phenotypic plasticity of the morphological traits of woody species in tropical dry forest for proper management and sustainable development of the forest ecosystem.
\end{abstract}

Keywords: phenotypic plasticity, morphological traits, tropical dry forest, soil moisture content
Volume 2 Issue 4 - 2018

\author{
Chaturvedi RK,' Pandey SK, ${ }^{2}$ Rahul \\ Bhadouria, ${ }^{3}$ Shivam Singh, ${ }^{2}$ Raghubanshi AS ${ }^{4}$ \\ 'Community Ecology and Conservation Group, Center for \\ Integrative Conservation, Xishuangbanna Tropical Botanical \\ Garden, Chinese Academy of Sciences, China \\ ${ }^{2}$ Ecosystems Analysis Laboratory, Department of Botany, \\ Banaras Hindu University, India \\ ${ }^{3}$ Natural Resource Management Laboratory, Department of \\ Botany, University of Delhi, India \\ ${ }^{4}$ Institute of Environment and Sustainable Development, Banaras \\ Hindu University, India
}

\author{
Correspondence: Chaturvedi RK, Community Ecology and \\ Conservation Group, Center for Integrative Conservation, \\ Xishuangbanna Tropical Botanical Garden, Chinese Academy of \\ Sciences, China, Tel +86 I8288059250, \\ Email ravikantchaturvedil0@gmail.com
}

Received: August 04, 2018| Published: August 29, 2018

\section{Introduction}

Although plant species share the key functional purpose, i.e., assimilation of photosynthetic carbon and transpiration, they exhibit wide variations in morphological traits. ${ }^{1-7}$ This property of a plant species to exhibit phenotypic variations according to changes in environmental conditions is commonly known as phenotypic plasticity of that plant species. ${ }^{8}$ The plasticity of any particular trait, possessing a genetic basis may also be adaptive, can increase the intensity or attenuate the evolved responses, and could itself show evolution in response to the selection on the basis of the range of spatial or temporal heterogeneity. ${ }^{7}$ The selection of functional traits can act on both forms, i.e., variation for traits and the variation for phenotypic plasticity of traits, therefore for understanding the evolution of plastic traits, it is necessary to investigate the complex interplay occurring between the plasticity in individual responses and the plasticity in evolved responses of populations.

Interspecific correlations observed among the ecologically significant plant traits attract the attention of ecologists working on the evolutionary aspects because they may exhibit two distinct phenomena. First, they may indicate morphological, physiological or developmental 'constraints' which limit the independent variation as well as evolution of the associated traits for a particular environmental condition, and second, the correlations might be the adaptive outcome due to natural selection which may favour particular combinations of traits compared to others, and in such case the set of traits are commonly said to form an ecological 'strategy' dimension. ${ }^{9}$ Proper understanding of differences between these ecological explanations and analysing the factors affecting trait-based strategy dimensions is essential because it provides us insight into life-history trade-offs which operate within as well as between environments, and also into important ecological phenomena, for example, niche differentiation, species coexistence and the large shifts in plant traits which occur along geographic gradients. The study described in this communication was executed in the Vindhyan Highlands situated in Sonebhadra District of Uttar Pradesh, India ( $21^{\circ} 29^{\prime}-25^{\circ} 11^{\prime} \mathrm{N}$ and $\left.78^{\circ} 15^{\prime}-84^{\circ} 15^{\prime} \mathrm{E}\right)$. For detail information about the various aspects of the study region, see Chaturvedi et al. ${ }^{10-16}$ On the basis of literature survey on tropical dry forests, we selected eight morphological traits (viz, girth, GT; height, HT; bark thickness, BT; wood specific gravity, WSG; leaf area, LA; crown cover, CC; crown depth, CD; leaf area index, LAI), which are considered important for the survival and growth of plant species in tropical dry forest, and measured their range in woody species, including trees and shrubs, across the five study sites. Further, we analysed the response of functional traits to variations in soil moisture content (SMC) across species as well as across study sites. For detail description of study design and the protocol for functional trait measurements, see Chaturvedi ${ }^{1}$ and Chaturvedi \& Raghubanshi. ${ }^{17}$ The phenotypic plasticity of plant traits for each species across the study sites were calculated following Callahan ${ }^{18}$ as:

$$
\text { Trait plasticity }=\left[1-\frac{\text { lowest value of plant trait across sites }}{\text { highest value of plant trait across sites }}\right] \times 1
$$

Results of the study showed that for trees, maximum GT $(104 \mathrm{~cm})$, HT $(17 \mathrm{~m})$, BT $(1.8 \mathrm{~cm})$ and LAI (14) were accounted by Shorea robusta, greatest WSG $\left(0.80 \mathrm{~g} \mathrm{~cm}^{-3}\right), \mathrm{CC}\left(28 \mathrm{~m}^{2}\right)$ and $\mathrm{CD}(7.8 \mathrm{~m})$ by Hardwickia binata and largest LA $\left(665 \mathrm{~cm}^{2}\right)$ by Sterculia urens (Table 1). In shrubs, maximum GT (24cm), HT (4m), BT (0.5 cm), LA $\left(31 \mathrm{~cm}^{2}\right), \mathrm{CC}\left(13 \mathrm{~m}^{2}\right)$ and $\mathrm{CD}(3 \mathrm{~m})$ were detected in Lantana camara, 
highest WSG $\left(0.7 \mathrm{gcm}^{-3}\right)$ in Carissa spinarum, and greatest LAI (3.9) in Woodfordia fruticosa (Table 2). The highest trait plasticity was observed for LA (99.2\% in trees and $97.5 \%$ in shrubs) and lowest in WSG $(50.0 \%$ in trees and $14.3 \%$ in shrubs) (Table 1$)$. Lowest LA was detected in Ziziphus glaberrima $\left(5.0 \mathrm{~cm}^{2}\right)$ at Kotwa and highest in Sterculia urens $\left(665 \mathrm{~cm}^{2}\right)$ at Hathinala, whereas, WSG was minimum in Sterculia urens $\left(0.4 \mathrm{~g} \mathrm{~cm}^{-3}\right)$ at Kotwa and maximum in Hardwickia binata $\left(0.8 \mathrm{gcm}^{-3}\right)$ at Ranitali (Table 1$)$. Lowest LA in shrubs was observed in Ziziphus oenoplea $\left(0.8 \mathrm{~cm}^{2}\right)$ at Kotwa and highest in Lantana camara $\left(31.4 \mathrm{~cm}^{2}\right)$ at Hathinala (Table 2). WSG of shrub species was minimum in Lantana camara $\left(0.6 \mathrm{gcm}^{-3}\right)$ at Hathinala and maximum in Carissa spinarum $\left(0.7 \mathrm{gcm}^{-3}\right)$ at Harnakachar (Table 2 ). The relationships of mean value of morphological traits across all woody species at the five study sites with the respective mean value of soil properties were mostly significant (Figure 1). Height (HT) of the plant species showed strongest relationship with clay content $(R=0.98, P<0.01)$. Soil properties such as bulk density (BD), $\mathrm{pH}$ and sand were negatively related with HT, whereas, SMC, C, N, P and clay were positively related with HT (Figure 1). Strongest relationship of BT was with sand $(R=0.91, P<0.05)$. This trait was positively related with $\mathrm{BD}, \mathrm{pH}$ and sand content but negatively related with $\mathrm{SMC}, \mathrm{C}$, $\mathrm{N}, \mathrm{P}$ and clay (Figure 1). WSG showed negative relationship with $\mathrm{SMC}, \mathrm{pH}, \mathrm{P}$ and clay, whereas, positive relationship with BD. Positive relationship of LA was detected with SMC, $\mathrm{P}$ and clay content but negative relationship with $\mathrm{BD}, \mathrm{pH}, \mathrm{C}, \mathrm{N}$ and sand (Figure 1). Plant crown cover (CC) was positively related with SMC, C, N, P and clay but showed negative relationship with $\mathrm{BD}, \mathrm{pH}$ and sand. Strongest relationship of $\mathrm{CD}$ was observed with $\mathrm{BD}(R=-0.99, P<0.01)$, which was significantly negative (Figure 1). The other soil properties showing negative relationship with $\mathrm{CD}$ were $\mathrm{pH}$ and sand, but $\mathrm{SMC}$, $\mathrm{C}, \mathrm{N}, \mathrm{P}$ and clay showed positive relationship with $\mathrm{CD}$. Leaf area index (LAI) showed strongest relationship with SMC $(R=0.96$, $P<0.05)$ as compared to other soil properties. SMC, C, N, P and clay were positively related with $\mathrm{LAI}$, whereas, $\mathrm{BD}, \mathrm{pH}$ and sand showed negative relationship with LAI (Figure 1).

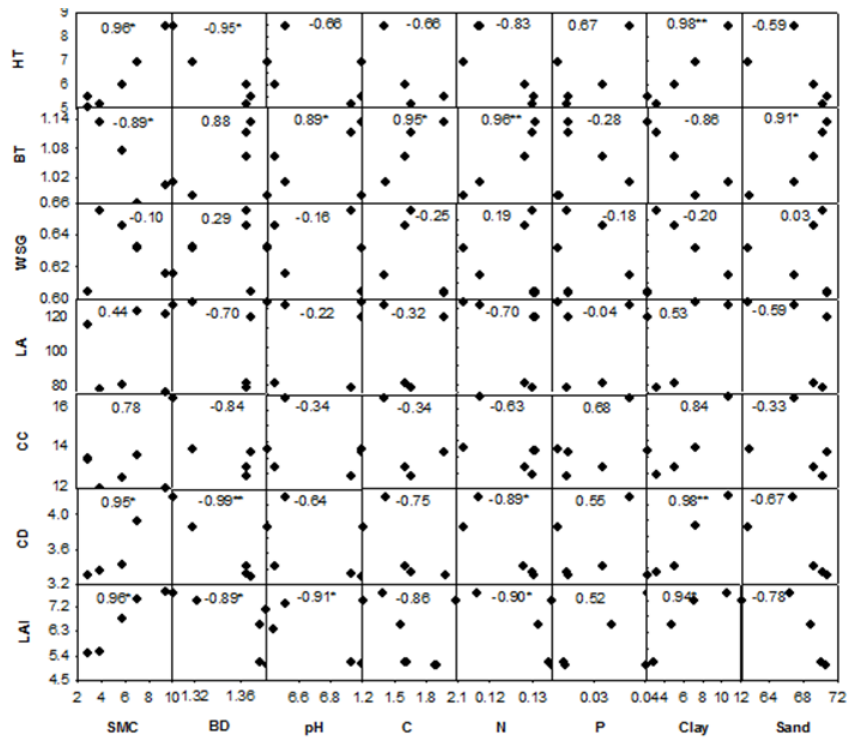

Figure I Relationships of morphological traits and soil properties of the five study sites. HT, height; BT, bark thickness; WSG, wood specific gravity; LA, leaf area; CC, crown cover; CD, crown depth; LAI, leaf area index; SMC, soil moisture content; $B D$, bulk density; $C$, organic carbon content; $N$, total nitrogen content; $\mathrm{P}$, total phosphorus content; $* \mathrm{P}<0.05$; $* * \mathrm{P}<0.0$ I. Numbers indicate $R$ values. Source: Chaturvedi'
Table I Range of morphological traits of tree species $(n=40)$ across the study sites. GT, girth; HT, height; BT, bark thickness; WSG, wood specific gravity; LA, leaf area; CC, crown cover; CD, crown depth; LAI, leaf area index; HN, Hathinala; GG, Gaighat; HK, Harnakachar; RT, Ranitali; KT, Kotwa. Source: Chaturvedi

\begin{tabular}{|c|c|c|c|c|}
\hline Trait & Min & Max & $\begin{array}{l}\text { Mean } \\
( \pm \text { S.E. })\end{array}$ & $\begin{array}{l}\text { Plasticity } \\
\text { (\%) }\end{array}$ \\
\hline GT (cm) & $\begin{array}{l}36.5 \text { (Ziziphus } \\
\text { nummularia, } \mathrm{HK} \text { ) }\end{array}$ & $\begin{array}{l}\text { I04 (Shorea } \\
\text { robusta, HN) }\end{array}$ & $\begin{array}{l}64.7 \\
( \pm 2.1)\end{array}$ & 64.7 \\
\hline $\mathrm{HT}(\mathrm{m})$ & $\begin{array}{l}4.10 \text { (Ziziphus } \\
\text { nummularia, } \mathrm{HK} \text { ) }\end{array}$ & $\begin{array}{l}16.7 \text { (Shorea } \\
\text { robusta, HN) }\end{array}$ & $\begin{array}{l}7.80 \\
( \pm 0.4)\end{array}$ & 75.4 \\
\hline BT $(\mathrm{cm})$ & $\begin{array}{l}0.60 \text { (Anogeissus } \\
\text { latifolia, } \mathrm{HN})\end{array}$ & $\begin{array}{l}\mathrm{I} .80 \text { (Shorea } \\
\text { robusta, GG) }\end{array}$ & $\begin{array}{l}1.20 \\
( \pm 0.1)\end{array}$ & 66.7 \\
\hline $\begin{array}{l}\text { WSG }(\mathrm{g} \\
\left.\mathrm{cm}^{-3}\right)\end{array}$ & $\begin{array}{l}0.40(\text { Sterculia } \\
\text { urens, KT) }\end{array}$ & $\begin{array}{l}0.80 \\
\text { (Hardwickia } \\
\text { binata, RT) }\end{array}$ & $\begin{array}{l}0.60 \\
( \pm 0 I)\end{array}$ & 50.0 \\
\hline $\mathrm{LA}\left(\mathrm{cm}^{2}\right)$ & $\begin{array}{l}5.00 \text { (Zizyphus } \\
\text { glaberrima, KT) }\end{array}$ & $\begin{array}{l}665 \text { (Sterculia } \\
\text { urens, HN) }\end{array}$ & $\begin{array}{l}155 \\
( \pm 28.4)\end{array}$ & 99.2 \\
\hline $\mathrm{CC}\left(\mathrm{m}^{2}\right)$ & $\begin{array}{l}9.40 \text { (Flacourtia } \\
\text { indica, GG) }\end{array}$ & $\begin{array}{l}28.4 \\
\text { (Hardwickia } \\
\text { binata, RT) }\end{array}$ & $\begin{array}{l}16.0 \\
( \pm 0.5)\end{array}$ & 66.9 \\
\hline$C D(m)$ & $\begin{array}{l}\text { I.80 (Flacourtia } \\
\text { indica, } \mathrm{HN})\end{array}$ & $\begin{array}{l}7.80 \\
\text { (Hardwickia } \\
\text { binata, RT) }\end{array}$ & $\begin{array}{l}4.20 \\
( \pm 0.2)\end{array}$ & 76.9 \\
\hline $\begin{array}{l}\mathrm{LAI}\left(\mathrm{m}^{2}\right. \\
\left.\mathrm{m}^{-2}\right)\end{array}$ & $\begin{array}{l}2.80(\text { Gardenia } \\
\text { turgida, } \mathrm{HN})\end{array}$ & $\begin{array}{l}\text { I } 4.0 \text { (Shorea } \\
\text { robusta, HN) }\end{array}$ & $\begin{array}{l}7.60 \\
( \pm 0.4)\end{array}$ & 80.0 \\
\hline
\end{tabular}

Table 2 Range of morphological traits of shrub species $(n=4)$ across the study sites. GT, girth; HT, height; BT, bark thickness; WSG, wood specific gravity; LA, leaf area; CC, crown cover; CD, crown depth; LAI, leaf area index; HN, Hathinala; GG, Gaighat; HK, Harnakachar; RT, Ranitali; KT, Kotwa. Source: Chaturvedi'

\begin{tabular}{|c|c|c|c|c|}
\hline Trait & Min & Max & $\begin{array}{l}\text { Mean } \\
( \pm \text { S.E. })\end{array}$ & $\begin{array}{l}\text { Plasticity } \\
(\%)\end{array}$ \\
\hline GT (cm) & $\begin{array}{l}7.50 \text { (Grewia } \\
\text { hirsuta, RT) }\end{array}$ & $\begin{array}{l}24.4 \\
\text { (Lantana } \\
\text { camara, HN) }\end{array}$ & $\begin{array}{l}15.6 \\
( \pm 2.5)\end{array}$ & 69.3 \\
\hline $\mathrm{HT}(\mathrm{m})$ & $\begin{array}{l}0.80 \text { (Grewia } \\
\text { hirsuta, RT) }\end{array}$ & $\begin{array}{l}3.70 \\
\text { (Lantana } \\
\text { camara, HN) }\end{array}$ & $1.50( \pm 0.3)$ & 78.4 \\
\hline BT $(\mathrm{cm})$ & $\begin{array}{l}0.30 \text { (Ziziphus } \\
\text { oenoplea, KT) }\end{array}$ & $\begin{array}{l}0.50 \\
\text { (Lantana } \\
\text { camara, HK) }\end{array}$ & $0.41( \pm 0.02)$ & 40.0 \\
\hline $\begin{array}{l}\text { WSG } \\
\left(\mathrm{gcm}^{-3}\right)\end{array}$ & $\begin{array}{l}0.60 \text { (Lantana } \\
\text { camara, } \mathrm{HN})\end{array}$ & $\begin{array}{l}0.70 \text { (Carissa } \\
\text { spinarum, } \\
\mathrm{HK} \text { ) }\end{array}$ & $0.61( \pm 0.02)$ & 14.3 \\
\hline $\mathrm{LA}\left(\mathrm{cm}^{2}\right)$ & $\begin{array}{l}0.80 \text { (Ziziphus } \\
\text { oenoplea, KT) }\end{array}$ & $\begin{array}{l}31.4 \\
\text { (Lantana } \\
\text { camara, HN) }\end{array}$ & $6.72( \pm 5.6)$ & 97.5 \\
\hline$C C\left(m^{2}\right)$ & $\begin{array}{l}0.70 \text { (Grewia } \\
\text { hirsuta, GG) }\end{array}$ & $\begin{array}{l}\text { I } 2.9 \\
\text { (Lantana } \\
\text { camara, HN) }\end{array}$ & $3.20( \pm 1.3)$ & 94.6 \\
\hline$C D(m)$ & $\begin{array}{l}0.60 \text { (Grewia } \\
\text { hirsuta, HK) }\end{array}$ & $\begin{array}{l}3.10 \\
\text { (Lantana } \\
\text { camara, HN) }\end{array}$ & I.20 ( \pm 0.2$)$ & 80.6 \\
\hline $\begin{array}{l}\mathrm{LAI}\left(\mathrm{m}^{2}\right. \\
\left.\mathrm{m}^{-2}\right)\end{array}$ & $\begin{array}{l}\text { I.20 (Grewia } \\
\text { hirsuta, HN) }\end{array}$ & $\begin{array}{l}3.90 \\
\text { (Woodfordia } \\
\text { fruticosa, } \\
\text { HK) }\end{array}$ & $2.81( \pm 0.4)$ & 69.2 \\
\hline
\end{tabular}

The morphological traits in our study are known to affect the 
performance of woody species either directly or indirectly. ${ }^{10-16}$ However, the intensity of their impact is determined mostly by environmental parameters, and in tropical dry forest, soil water availability has been reported as the most important factor ${ }^{19-22}$ Stepwise multiple regression indicated that among the eight morphological traits, 56\% variability in species richness (SR) was only explained by LA, while LA and HT together explain $65 \%$ variability in SR of the woody species. The model developed by step-wise multiple regression was $S R=0.459+0.814 L A-0.282 H T$. The variables in the model represent quantity of photosynthetic surface and water use economy of a species.

\section{Conclusion}

In the extremely variable and severe environment of tropical dry forest, the phenotypic plasticity of morphological traits of plant species plays an important role for their development, functioning and evolution. In our study, the woody species exhibited wide range of morphological traits. The phenotypic plasticity of the morphological traits showed remarkable variation across species as well as within a particular species growing at different levels of soil moisture content. The relationships of mean value of morphological traits across all woody species at five study sites with the respective mean value of soil properties were significant. Among the selected traits, LA and HT were most important for the variation in SR at our study sites. We suggest extensive investigation of the phenotypic plasticity of the morphological traits of woody species in tropical dry forest for proper management and sustainable development of the forest ecosystem.

\section{Acknowledgements}

RKC thanks Council of Scientific and Industrial Research, India (award no. 09/13(452)/2012-EMR-I) and Natural Science Foundation of China (NSFC), Chinese Academy of Science, China (grant No. 31750110466) for financial support. RB is thankful to UGC (BSR/ BL/17-18/0067) for providing Dr. DS Kothari fellowship for Post Doctoral Research.

\section{Conflict of interest}

The authors declare there is no conflict of interest.

\section{References}

1. Chaturvedi RK. Plant functional traits in dry deciduous forests of India. PhD thesis. Department of Botany. Banaras Hindu University, Varanasi, India. 2010.

2. Chaturvedi RK, Raghubanshi AS, Singh JS. Plant functional traits with particular reference to dry deciduous forests: a review. Journal of Biosciences. 2011a;36(5):963-981.

3. Chaturvedi RK, Raghubanshi AS, Singh JS. Leaf attributes and tree growth in a tropical dry forest. Journal of Vegetation Science. 2011b;22(5):917931.

4. Chaturvedi RK, Raghubanshi AS. Phenotypic plasticity in functional traits of woody species in tropical dry forest. Janet B Valentino, Patricia C, editors. Phenotypic Plasticity: Molecular Mechanisms, Evolutionary Significance and Impact on Speciation. Harrelson, Nova Science Publishers, Inc. NY 11788 USA. 2013;35-66.

5. Chaturvedi RK, Raghubanshi AS, Singh JS. Growth of tree seedlings in a dry tropical forest in relation to soil moisture and leaf traits. Journal of Plant Ecology. 2013;6(2):158-170.
6. Chaturvedi RK, Raghubanshi AS, Singh JS. Relative effects of different leaf attributes on sapling growth in tropical dry forest. Journal of Plant Ecology. 2014;7(6):544-558.

7. Singh JS, Chaturvedi RK. Tropical Dry Deciduous Forest: Research Trends and Emerging Features. Springer Nature Singapore Pte Ltd., Singapore. 2018.

8. Sultan SE. Phenotypic plasticity for plant development, function and life history. Trends in Plant Science. 2018;5(12):537-542.

9. Westoby M, Falster DS, Moles AT, et al. Plant ecological strategies: Some leading dimensions of variation between species. Annual Review of Ecology and Systematics. 2002;33:125-159.

10. Chaturvedi RK, Raghubanshi AS, Singh JS. Effect of small scale variations in environmental factors on the distribution of woody species in tropical deciduous forests of Vindhyan Highlands, India. Journal of Botany. 2011c:1-10.

11. Chaturvedi RK, Raghubanshi AS, Singh JS. Carbon density and accumulation in woody species of tropical dry forest in India. Forest Ecology and Management. 2011d;262(8):1576-1588.

12. Chaturvedi RK, Raghubanshi AS, Singh JS. Effect of grazing and harvesting on diversity, recruitment and carbon accumulation of juvenile trees in tropical dry forests. Forest Ecology and Management. 2012;284:152-162.

13. Chaturvedi RK, Raghubanshi AS. Species Composition, Distribution and Diversity of Woody Species in tropical dry forest of India. Journal of Sustainable Forestry. 2014;33(8):729-756.

14. Chaturvedi RK, Raghubanshi AS. Assessment of carbon density and accumulation in mono- and multi-specific stands in Teak and Sal forests of a tropical dry region in India. Forest Ecology and Management. 2015;339:11-21.

15. Chaturvedi RK, Raghubanshi AS, Singh JS. Sapling harvest: A predominant factor affecting future composition of tropical dry forests. Forest Ecology and Management. 2017a;384:221-235.

16. Chaturvedi RK, Raghubanshi AS, Tomlinson KW, et al. Impacts of human disturbance in tropical dry forests increase with soil moisture stress. Journal of Vegetation Science. 2017b;28(5):997-1007.

17. Chaturvedi RK, Raghubanshi AS. Plant Functional Traits in a Tropical Deciduous Forest: An analysis. Lambert Academic Publishing GmbH \& Co. KG, Berlin, Germany. 2011.

18. Callahan HS. Using artificial selection to understand plastic plant phenotypes. Integrative and Comparative Biology. 2005;45:475-485.

19. Chaturvedi RK, Raghubanshi AS. Leaf life-span dynamics of woody species in tropical dry forests of India. Tropical Plant Research. 2016;3(1):199-212.

20. Chaturvedi RK, Raghubanshi AS. Soil water availability influences major ecosystem processes in tropical dry forest. International Journal of Hydrology. 2018a;2(1):00042.

21. Chaturvedi RK, Raghubanshi AS. Effect of Soil Moisture on Composition and Diversity of Trees in Tropical dry Forest. MOJ Ecology \& Environmental Science. 2018b;3(1):00059.

22. Chaturvedi RK, Raghubanshi AS. Application of ordination methods for determining influence of soil properties on woody species assemblage in tropical deciduous forest. International Journal of Hydrology. 2018c;2(3):296-298. 